\title{
TEACHER GUIDANCE AND COUNSELING EFFORTS TO PREVENT CHEATING BEHAVIOR
}

\author{
Riska Ahmad ${ }^{\mathrm{a}}$ \\ ${ }^{\mathrm{a}}$ Guidance \& Counselling Department, Faculty of Science Education, State University of Padang \\ Corresponding e-mail: riska_ahmad@yahoo.com
}

\begin{abstract}
Academic dishonesty or cheating is behaviour that is done by the students, they have become a serious problem in the world. One of the functions of guidance and counselling teacher is to prevent the occurance of bad behaviour. So, guidance and counselling teachers should strive to prevent cheating behaviour. The purpose of this study is to describe teacher guidance and counselling efforts in preventing cheating behaviour, and to examine whether there are differences in the efforts of guidance and counselling teachers in preventing cheating behaviour in terms of their length of working and at the school where they work. The population are guidance and counselling teachers in junior and senior high school, amounting to 237 people. The determination of the sample by purposive random sampling technique by considering the length of work of the teacher, with sample is 100 guidance and counselling teachers. Instrument used is rating scale. By using the hypothetical mean, research results show that $33 \%$ guidance and counsellor teachers quite optimal efforts, $29 \%$ optimal, and $11 \%$ very optimal to prevent cheat behaviour. No different effort guidance and counseling teachers in terms of long work and school work place.
\end{abstract}

Keywords: effort, prevent, academic dishonesty/ cheating, guidance and counselling teacher

\section{INTRODUCTION}

Honesty is one character that must be owned by everyone. Honesty needs to be nurtured and developed within a person through the process of education. The fact shows that dishonesty happens in all aspects of life, including in education. It's called cheating or academic dishonesty.

Ehrlich et al [1] define cheating in general as behaving "dishonestly or unfairly in order to win some profit or advantage". Siercles at al [2] defined "cheating as copying from another student or from unauthorized notes during an examination, previewing the examination illicitly, submitting someone else's work as one's own, plagiarizing, falsifying experimental data, and asking another student for answers to an examination that one student had taken but the other had not". Kusnoor \& Falik [2] define cheating as "copying answers (from a student or notes), trading examination answers, illicitly previewing an examination, submitting someone else's work, asking another student for answers to an examination for another student, altering grades in the record and moving labels or altering slides in an examination.
Academic cheating has been studied in different countries including the USA (McCabe and Trevino, 1997 McCabe, 2001, 2009), the UK (Kirkland, 2009), and Canada (Widerman, 2009), [3] According studied [4] to students engineering indicated $63,8 \%$ respondents cheating at least a few times per term, and 79,2 \% of the respondents indicated that they cheated at least once per term. Whitley reported between $40 \%$ and $70 \%$ of students report having cheated at least once in college [5]. McCabe and Trevino's[6] study of almost 1800 students at nine medium-to large-size universities in the 1993-1994 academic year examined the relative influence of contextual and individual factors on cheating behaviour, and the results pointed to the primacy of the institutional context in influencing cheating behaviour. The contextual factors (peer cheating behaviour, peer disapproval of cheating behaviour, and perceived severity of penalties for cheating) were significantly more influential than the individual factors (age, gender, GPA, and participation in extracurricular activities). McCabe et al [6], identified other factors that can influences cheating, including pressure to get high grades, parental pressures, a desire to excel, pressure to get a job, laziness, a lack of 
responsibility, a lack of character, poor of selfimage, a lack of pride in a job well done, and a lack of personal integrity. Spiegel and Whitley, [8] concludes about the powerful influence of institutional context on students decisions to cheat, between the 1960s and 1990, most of the research on student cheating focused on the role of individual factors related to cheating behaviour. The individual factors such as gender, cumulative grade point average (CGPA), work ethics, type A behaviour, competitive achievement striving, and self-esteem can significantly influence the prevalence of cheating. S. Batool, A. Abbas, \& Z. Naeemi [8] found their study that there is high positive correlation of parental pressure with the students being grade oriented. Also a positive relationship was between the students' lack of preparation and their urge to cheat. Another finding on the study was, that if a student is grade oriented, then they would cheat if environment and invigilation allows. A very important finding was that when the exam difficulty level is high, then the student would want/try to cheat despite the strict invigilation, if the environment allows, then they would definitely cheat. Callahan [9] that there are four underlying reasons that motivate people to cheat: 1) new pressures, 2) temptation, 3) bigger rewards for winning and, 4) trickle-down corruption. Rajendran [2] reported that the primary reason for cheating is because the student may not have studied and thus inefficient to write an exam or complete an assignment. [3] reported the result of study from Dans, Wajda-Jonson, Handal, Brawer,et al, that the pressure to succeed can induce both undergraduates and medical students to cheat. Park, Park and Jang [4], reported the reason academic cheating among nursing students in South Korean are want to earn a higher grades, not have enough time, want to get a better job in the future, not motivated to study for an exam or to complete an assignment. There are surveys finding between $40 \%$ and $70 \%$ of students report having cheated at least once in college, [5]. Rajendran reported that statistics show among highschool and college students has risen drastically during the past 50 years. The results of the 29th Who's Who Among American High School Students Poll were released in November, 1998. Among the findings are, 1) $80 \%$ of the country's best students cheated to get to the top of their class, 2) more than half students surveyed said that they don't think cheating is a big deal, 3) $95 \%$ of cheater say they were not caught, $40 \%$ cheated on a quiz or a test, $67 \%$ copied someone else's homework. In South of Korea, surveyed to nursing students [3], the results indicated that $50 \%$ and $78 \%$ of students were engaged in, respectively, exam-cheating and assignment cheating behaviours.

Agustin, [10] conducted a research on the behaviour of cheating in high school at Padang, West Sumatra Indonesia, it was found that from 394 students, 74, $8 \%$ students copy answers friend and $27,1 \%$ cheat by using notes. As for the factors that affect the appearance of cheating is $63 \%$ students answered their to get high score, $77,1 \%$ want to avoid failure, $56 \%$ the perception of student that school do not fair, and $46 \%$ lack of time to complete school assignment.

Cheating behaviour must be prevented. One of the functions of guidance and counselling is to prevent the occurrence of bad behaviour, including to prevent the occurrence of cheating behaviour. According [2], "the prevention of the unethical behaviours requires multiple strategies: promoting a culture of academic integrity at the institutional level, which includes preventing burnout, focusing on learning, integrating ethics throughout the curriculum, teaching peer review, and providing faculty development". Azuka and Oyaziwo [11], school counsellor may consider advocating the introduction of an examination ethics club and through the club activities, useful information would be disseminated to all student and staff of institutions. School counsellor could even go further by collaboration with the examination ethics club to arrange debates in the media to create public awareness about virtues of examination ethics. The school counsellor by the virtue of his/her training is well equipped to guides students towards achieving optimal behaviour during the conduct of examination. By effective communication between counsellors and students, counsellor and teacher, counsellor and the principals, and school counsellor and significant others: giving impromptu talks to individuals and groups of students on the expected behaviour before and during examination; delivering lectures on how to study effectively and prepare for examinations; formulating and adopting a personalreading time table; organizing talks, exam ethics and sanction to all students at the beginning of every time and a week before the examination; informing teachers/invigilators on the expected behaviour during examination; and encouraging subjectteachers to refer students who need academic counselling to the counsellors in good time.

Stephens and Wangaards [12] recommended specifics strategies for reducing different types of dishonety 1) reducing homework cheating, 2) reducing in class test cheating, 3) preventing 
plagiarism, 4) detecting plagiarism, and 5) confronting suspected plagiarism. Result of research [6] adopted by student comments in McCabe, Trevino, and Butterfield (1999) about how to prevent cheating in academic institutions 1) clearly communicate expectations, 2) establish and communicate cheating politics and encourage students to abide by those policies, 3) establishing a classroom honour code, 4) be supportive when dealing with students, this promotes respect, which students will reciprocate by not cheating, 5) be fair, 6) when possible, reduce pressure by not grading students on a strict curve, 7) focus on leading, not on grades, 8) encourage the development of good character, 9) provide detterents to cheating, 10) remove opportunities to cheat, 11) assign interesting and nottrivial assignments, and 12) replace incompetent or apathetic teaching assistants. From McCabe \& Pavela [6], there are ten principles for managing cheating in the class: 1) affirm the importance of academic integrity, 2) foster in love learning, 3) treat students as an end in themselves, 4) foster and environment of trust in the classroom, 5) encourage student responsibility for academic integrity, 6) clarify expectations for students, 7) develop fair and relevant forms of assessment, 8) reduce opportunities to engage in academic dishonesty when it occurs, and 10) help define and support campus-wide academic integrity standarts.

From American School Counsellor Association (ASCA) [13] about "the role of the School Counsellor" school counsellor provide services to students, parents, school staff and the community in the following areas direct services with students include: school counselling core curriculum, individual student planning, and responsive services. The second is indirect services for students. School counsellor create comprehensive school counsellor counselling programs that focus on student outcomes, teach students competencies and are delivered with identified professional competencies and are delivered with identified professional competencies. For students competencies the school counsellor enhance the learning process for all students, the ASCA Mindsets \& Behaviours for Students Success guide the development of effective school counselling program around three domains: academic, career and social/ emotional development.

The government through the Ministry of Education and Culture established a policy about the Teacher Professional Development which is the implementation of constitution number 14 in 2005 , Table 1. Teacher Guidance and Counselling Efforts to Prevent Cheating Behaviour and government regulation number 74 in 2008. It is suggested that become a teacher must meet the requirements of qualified Strata 1 or Diploma 4, and must obtain a teacher certificate. There are 4 steps to professional teachers, namely the provision of college-based teachers (strata 1/diploma IV), induction of novice teachers, institutional-based teacher-based professionalism, and individual teacher-based professionalism to become civil masters. Professionalism of the teachers can be seen through competency; personal competence, social competence and pedagogic competence. By mastering these competencies, guidance and counselling teachers can prevent the occurrence of cheating behaviour.

Thus, the purpose of this study is to describe the efforts of guidance and counselling teachers in preventing cheat behaviour, and to examine whether there are differences in the efforts of teachers in preventing cheating behaviour in terms of their long service life.

\section{METHODS}

Population in this study is guidance \& counselling teachers in yunior high school, and senior high school in Padang, totalling 237 teachers with sample 100 guidance \& counselling teachers, whose working period is between 1 year to 36 years. Instrument used is rating scale developed by [14] which consists of 46 items built with the concept of Conyne (2004). Each item provided five alternative answer are always, often, sometime, rarely and never. Instrument reliability by using Cronbach's alpha .864, while its content validity is tested with procedure product moment correlation.The data obtained is processed by statistical procedure; Mean, Standart Deviation and t- test.

\section{RESULT AND DISCUSSION}

\subsection{Teacher Guidance and Counselling Efforts to Prevent Cheating Behaviour}

Various attempts by guidance and counselling teachers to prevent students from cheating. There are two efforts, providing information, skills training in learning and develop the right attitudes toward cheating behaviour. 


\begin{tabular}{|c|c|c|c|c|c|c|}
\hline \multirow[t]{2}{*}{ No } & \multirow{2}{*}{ Indicator } & \multicolumn{5}{|c|}{ Category Implementation (\%) } \\
\hline & & Always & Often & Sometimes & Rarely & Never \\
\hline 1. & Information about impact of cheats & 59,3 & 35,43 & 4,4 & 0,85 & 0 \\
\hline 2. & Train learning skills & 14,4 & 48,07 & 31,5 & 5,38 & 0 \\
\hline 3. & Train students to make decisions not to cheat & 30,24 & 46,07 & 20,48 & 2,47 & 0,7 \\
\hline 4. & Train students not to worry in the exam & 37,98 & 43,94 & 14,86 & 1,95 & 0,7 \\
\hline 5. & Train social skills to avoid cheating behavior & 32,41 & 50,11 & 13,78 & 1,47 & 1,7 \\
\hline 6. & Strengthening attitudes and effective learning habits & 28,46 & 44,9 & 10,0 & 2,01 & 0.76 \\
\hline 7. & Stabilization of learning discipline & 33,46 & 49,17 & 13,18 & 3,39 & 0,8 \\
\hline 8. & Stabilization of mastery of learning program materials & 49,89 & 42,12 & 6,5 & 1,53 & 0 \\
\hline 9. & $\begin{array}{l}\text { Consolidating understanding of the physical, social and } \\
\text { environmental conditions of the school }\end{array}$ & 24,94 & 52,07 & 18,83 & 3.7 & 0,9 \\
\hline
\end{tabular}

Table 2. Quality Efforts Guidance \& Counselling Teachers Prevent Cheating Behaviour $(\mathrm{N}=100)$

\begin{tabular}{cllcc}
\hline \multicolumn{1}{c}{ No } & Quality of effort & \multicolumn{1}{c}{ Criteria } & Score Interval & Persentage \\
\hline 1. & Very Optimal & $\geq$ Mean + 1,5 SD & $218-230$ & $11 \%$ \\
\hline 2. & Optimal & $\geq$ M + 0,5 SD s.d $<+$ M 1,5 SD & $200-217$ & $29 \%$ \\
\hline 3. & Simply Optimal & $\geq$ M - 0,5 SD s.d <+ M 0,5 SD & $181-199$ & $33 \%$ \\
\hline 4. & Less Optimal & $\leq$ M - 1,5 SD s.d < M- 0,5 SD & $163-180$ & $19 \%$ \\
\hline 5. & Not Optimal & $\geq$ M - 1,5 SD & $\leq 162$ & $8 \%$ \\
\hline
\end{tabular}

First, is provide information about the effect of cheating behaviour. Effects of cheat behaviour are the loss of self-confidence, making students lazy, and failed future. Research [15] shows there is a significant negative correlation between selfconfidence with cheating behaviour. This implies that the higher the self-confidence, the lower the cheat behaviour. Cheating makes students lazy. Laziness makes the students do not master the subject matter. The concept of learning for mastery originally proposed by Bloom [16]. If students do not master the subject matter, they fail to the higher grade and consequently drop-out. Prayitno [17] argued that to achieve mastery in learning can be done by studying effectively.

Second, train students with learning skills and attitudes, such as recording skills, effective reading skills, summary crafting skills and so on. Developing attitudes and learning habits is an attempt to have students self-regulated in learning. According to Zimmerman and Schunk [18] that self regulated theories focus on how students encourage, change and maintaining learning activities.

According Glynn, Aultman \& Owens, [19] that "Self-regulated learning is a combination of academic learning and self-control skills that make learning easier for students to be more motivated".Thus, by improving students' selfregulated learning, improving student discipline in learning, can cope with school and environmental demands, and can prevent students from cheating.

Guidance and counselling teachers should also train students to avoid anxiety in the exam. There are several techniques that can be done to reduce the anxiety of students in the exam. Research conducted by [20], showed that there was a decrease in student anxiety after following supportive therapy. Research [21] showed that there is a decrease in anxiety students in exam using group counselling services using peer group discussion techniques. Further, research [22] showed the results that there is a decrease in student anxiety score after following group guidance with the technique of Spiritual Emotional Freedom.

\subsection{The quality of Guidance and Counselling Teacher's efforts in Preventing Cheating Behaviour}

Quality of teacher guidance \& counselling effort by using hypothetical mean, can be seen in table 2 . There is $33 \%$ of guidance and counselling teacher's effort in preventing cheating behaviour on optimal enough category, $29 \%$ optimal and $11 \%$ is very optimal, even $19 \%$ less than optimal, and $8 \%$ is not optimal. Therefore, the efforts of guidance and counselling teachers to prevent cheating behaviour should be improved. For guidance and counselling teachers whose activities have been optimally and very optimally need to be maintained. while for guidance and counselling teachers whose activities are less optimal or not optimal should be improved.

In the schools in Indonesia there cheat behaviour. The guidance and counselling teachers must improve their ability to prevent cheating 
behaviour. In Indonesia there is guidance and counselling teachers organization in the school that is MGBK (Musyawarah Guru Bimbingan Konseling). The guidance and counsellor teachers in junior high school (SMP), senior high school (SMA) vocational school (SMK) meet once a month in MGBK. In this meeting the guidance and counselling teachers get knowledges and skills related to guidance and counselling activities. Therefore, the guidance and counselling teachers should be able to use these opportunities to improve their skills. In addition, the guidance and counsellor teachers can also continue their education to S2, S3.

\subsection{The difference of effort from long working and school work place}

The working period of guidance and counselling teachers set as from 1 year up to 36 years. Obtained mean 16.41, with SD 10.35. In term working period of guidance and counselling teachers in junior high school, mean obtained is $\leq 10$ years was 188.68 , with SD 19, 07, and the working period $\geq 11$ years obtained mean of 194.61 with SD 17.14, while for teachers the guidance and counselling of senior high school with $\leq 10$ years was service period is 189.90 , with SD 19.34 and the mean of service period $\geq 11$ years is 195.83 with SD 25.45. Using the t-test formula, the following results are obtained on table 3

Table 3. Different Efforts Guidance and Counselling Teachers in Term Working Priode at SMP/ Junior High School (N=49)

\begin{tabular}{|c|c|c|c|c|c|}
\hline \multirow[t]{2}{*}{ Effort } & \multicolumn{2}{|c|}{$\begin{array}{l}\text { Levine's Test } \\
\text { for Equality } \\
\text { of Variances }\end{array}$} & \multicolumn{3}{|c|}{$\begin{array}{l}\text { t-test for equality of } \\
\text { Means }\end{array}$} \\
\hline & $\mathbf{F}$ & Sig. & $\mathbf{t}$ & df & $\begin{array}{c}\text { Sig (2 } \\
\text { tailed) }\end{array}$ \\
\hline $\begin{array}{c}\text { Equal } \\
\text { variances } \\
\text { assumed }\end{array}$ & .156 & .695 & $\begin{array}{c}- \\
1,089\end{array}$ & 47 & .282 \\
\hline $\begin{array}{c}\text { Equal } \\
\text { variances not } \\
\text { assumed } \\
\end{array}$ & & & $\begin{array}{c}- \\
1,120\end{array}$ & 38,844 & .269 \\
\hline
\end{tabular}

Based on table 3 and table 4 it can be seen that there is no difference in the effort of guidance and counsellor teachers who work for 10 years with guidance and counsellor teachers who work more than 10 years, both in SMP and SMA. In Indonesia the guidance and counsellor teachers are required to attend various workshops, but the workshop has not been able to improve the ability of guidance and counselling teachers in preventing cheating

behaviour. Therefore it is necessary to analyze the implementation of the workshop.

In terms of the time of completion of the guidance and counsellor teacher's, the guidance and counsellor teacher with ten years and above worked long enough to finish their lecture, while the guidance and counsellor teachers with a long time of 1-10 years, just finished their studies. It is known that the curriculum of guidance and counselling program study is always revised, the organization of lectures is further improved. Besides, the lecturer also has a minimum diploma S2. And so also facilities and infrastructure has also been more complete. It makes graduates more professional now.

Table 4. Different Efforts Guidance and Counselling Teachers in Term Working Periode at SMA/ Senior High School $(\mathrm{N}=51)$

\begin{tabular}{|c|c|c|c|c|c|}
\hline \multirow[t]{2}{*}{ Effort } & \multicolumn{2}{|c|}{$\begin{array}{l}\text { Levine's Test } \\
\text { for Equality } \\
\text { of Variances }\end{array}$} & \multicolumn{3}{|c|}{$\begin{array}{l}\text { t-test for equality of } \\
\text { Means }\end{array}$} \\
\hline & $\mathbf{F}$ & Sig. & $\mathbf{t}$ & df & $\begin{array}{l}\text { Sig (2 } \\
\text { tailed) }\end{array}$ \\
\hline $\begin{array}{c}\text { Equal } \\
\text { variances } \\
\text { assumed }\end{array}$ & .628 & .432 & .900 & 49 & .373 \\
\hline $\begin{array}{c}\text { Equal } \\
\text { variances } \\
\text { not } \\
\text { assumed }\end{array}$ & & & .944 & 48.613 & .350 \\
\hline
\end{tabular}

\section{CONCLUSIONS}

Some guidance and counselling teachers have attempted to prevent students cheating. The efforts are providing information about the impact of cheating and train learning skills so that students have self-regulated learning. The train is also done to reduce the anxiety of the exam

There is no difference in the effort of the guidance and counsellor teacher, whose working period is less than 10 years with the guidance and counsellor teacher with the working period of more than 10 years.

\section{REFERENCES}


[1] G. Orosz, I. Toth-Kiraly, B. Bothe Kusztor, U. $\mathrm{Z}$ Kovacs, and $\mathrm{M}$. Janvari, "Teacher enthusiasm: a potential cure of academic cheating", Frontier in Psychology, Original Research, 31 Maret 2015, doi: 10.3389/fpsyg.2015-00318.

[2] A. Rajendran, "Research Paper on Cheating", Computer Science Department Illinois Institute of Technology, Chicago, Illinois/CS560

[3] A. V. Kusnoor, R. Falk, "Cheating in medical school: the unacknowledged ailment", Southern Medical Journal, Volume 106, Number 8, August 2013, 479-483.

[4] E. J. Park, S. Park, I-S, Jang, “ Academic cheating among nursing students" Nurse Education Today 33, 2013, pp 346- 352

[5] T. S. Harding, D.D. Carpenter, J. F. Finelli, and J. H. Passow, "Does academic related unethical behavior in professional practice? an exploratory study", Science and Engineering Ethics . 2004. Volume10, Issue 2, 311-324.

[6] J. M. Wryobeck, B. E. Whitley. Jr, “ Educational value orientation and peer perception of cheaters" Ethics Behaviour, 9:3, 231-242, DOI: 10.1207/s 15327019eb0903 4

[7] D. L. McCabe, L. K. Trevino, K. D. Butterfield, "Cheating in academic institutions: A decade of research", Ethics \& Behaviour, 2001, 11 (3), pp 219-232.

[8] S. Batool, A. Abbas, \& Z. Naeemi, "Cheating Behavior among Undergraduate Students", International Journal of Business and Social Science, Vol 2, No 3. pp 246-255 Special Issue- January 2011.

[9] R.D. Danielsen, A.F. Simon, and R. Pavlick, "The culture of cheating: from the clasroom to the exam room", The Journal of Physician Assistant Education, 2006, Vol 17 No 1.

[10] V. Agustin, A. Sano, and I. Ibrahim, "Perilaku menyontek siswa SMA Negeri Kota Padang, serta upaya pencegahan oleh guru BK”. Konselor Jurnal Ilmiah Konseling, Volume 2, Nomor 1, Februari 2013

[11]N. G. Alulu. Azuka, A. Oyaziwo. "The role of counseling in dealing with examination malpractices and ethics", Revista Espanola de Orientacion Psicopedagogia, Vol 16, no 2 Julio-Deciembre, 2005, pp 189-198

[12] J. M. Stephens, D. B. Wangaard, "Teaching for Integrity: Steps to prevent cheating in your clasroom", The School for Efhical Education. http://www.ethicsed.org/programs/integrityworks/indexs.htm.

[13]ASCA, The Role of the School Counselor $\mathrm{http} / /$ :School counselor.org/asca/ /home/RoleStatement.pdf

[14]H. Ghoffar, 2016. Upaya guru mata pelajaran dan guru BK dalam mencegah perilaku menyontek, Disertasi Padang: UNP, unpublished.

[15]A. Kushartanti, "Prilaku menyontek ditinjau dari segi kepercayaan diri”, Indigenous: Jurnal Ilmiah Psikologi, 2009, hal 36-48 DOI: https:// doi.org/10.23917/ indigenous.v11i2.1658

[16] W. E. Elliot, “ Benyamin Bloom” International Bureau of Education, $2000 \mathrm{Vol}$ XXX, No 3 pp 3-5

[17] Prayitno. 2009 Pendidikan; dasar teori dan praksis, Padang: UNP Press.

[18]T. Damayanti, "Efektivitas intervensi ketrampilan self-regulated dan keteladanan dalam meningkatkan kemampuan belajar mandiri dan prestasi belajar mahasiswa pendidikan jarak jauh." Jurnal Pendidikan Terbuka dan Jarak Jauh, 2008, pp 68-72.

[19] E. Latipah. "Strategi self-regulated larning dan prestasi belajar; kajian Meta analisis". Jurnal Psikologi, 2010. Jurnal ugm.ac.id

[20] K. G. Swasti, C. D. Helena Novi, H. Pujasari, "Penurunan ansietas dalam menghadapi ujian nasional pada siswa kelas XII SMAN X melalui pemberian terapi suportif'. Jurnal Keperawatan Soedirman, (2013)Vol 8 No 2, hal 127-142

[21] Tuyanto, "Efektfitas bimbingan kelompok dengan teknik diskusi kelompok sebaya untuk mengurangi kecemasan dalam menghadapi ujian”, 2012, eprints.ums, ac.id, hal 1-17.

[22]E. Yunita, H. Warsito, E. Darminto, dan R. Lukitaningsih, "Penerapan Spritual Freedom Technique dalam bimbingan kelompok untuk menurunkan kecemasan siswa SMA menghadapi ujian" Jurnal BK Unesa Vol 03 No 1 (2013), hal 201-297. 